\title{
Lucien Steil
}

\section{The Reconstruction of Aleppo}

\section{La reconstrucción de Alepo}

A reconstrução de Alepo

\begin{abstract}
Resumen $\mid$ Resumo
Human history is marked by a dramatic dialectic of "destruction" and "reconstruction", the record of which has itself often been lost. Yet memories of tragic destructions and often heroic reconstructions remain ingrained in the history, archaeology, and myths of all civilizations. Whereas the predominantcontemporaryideology of architecture seems to prefer "deconstruction" and the consecration of an imagery of fragmentation and desolation, the Reconstruction of Aleppo project proposes a traditional strategy of material and moral reconstruction. Such reconstruction seeks not only to repair and recompose the form and meaning of homes and places but also to allow for reconciliation and healing, as well as confidence and identity.
\end{abstract}

La historia de la humanidad está marcada dramáticamente por la dialéctica de la "destrucción" y la "reconstrucción", cuyo registro a menudo se ha perdido. Pero los recuerdos de estas destrucciones trágicas y estas reconstrucciones a menudo heroicas quedan grabados en la historia, la arqueología y los mitos de todas las civilizaciones. Mientras que la ideología actual predominante en la arquitectura parece preferir la "deconstrucción" y la consagración de un imaginario de fragmentación y desolación, el proyecto de Reconstrucción de Alepo propone una estrategia tradicional de reconstrucción material y moral. La reconstrucción no solo intenta rehabilitar y recomponer la forma y el significado de los hogares y los lugares, sino que posibilita la reconciliación y promueve que se cierren las heridas, así como que se mantengan la confianza y la identidad.

A história da humanidade é marcada de forma dramática pela dialéctica da "destruição" e "reconstrução", cujo registo se perdeu muitas vezes; memórias destas trágicas destruições e reconstruções muitas vezes heróicas permanecem enraizadas na história, arqueologia, e mitos de todas as civilizações. Enquanto a ideologia predominante da arquitectura contemporânea parece preferir a "desconstrução" e a consagração de um imaginário de fragmentação e desolação, o projecto Reconstrução de Alepo propõe uma estratégia tradicional de reconstrução material e moral. Este empreendimento de reconstrução procura não só reparar e recompor a forma e o significado das casas e lugares das pessoas, mas também permitir a reconciliação e a cura, assim como a confiança e a identidade. 


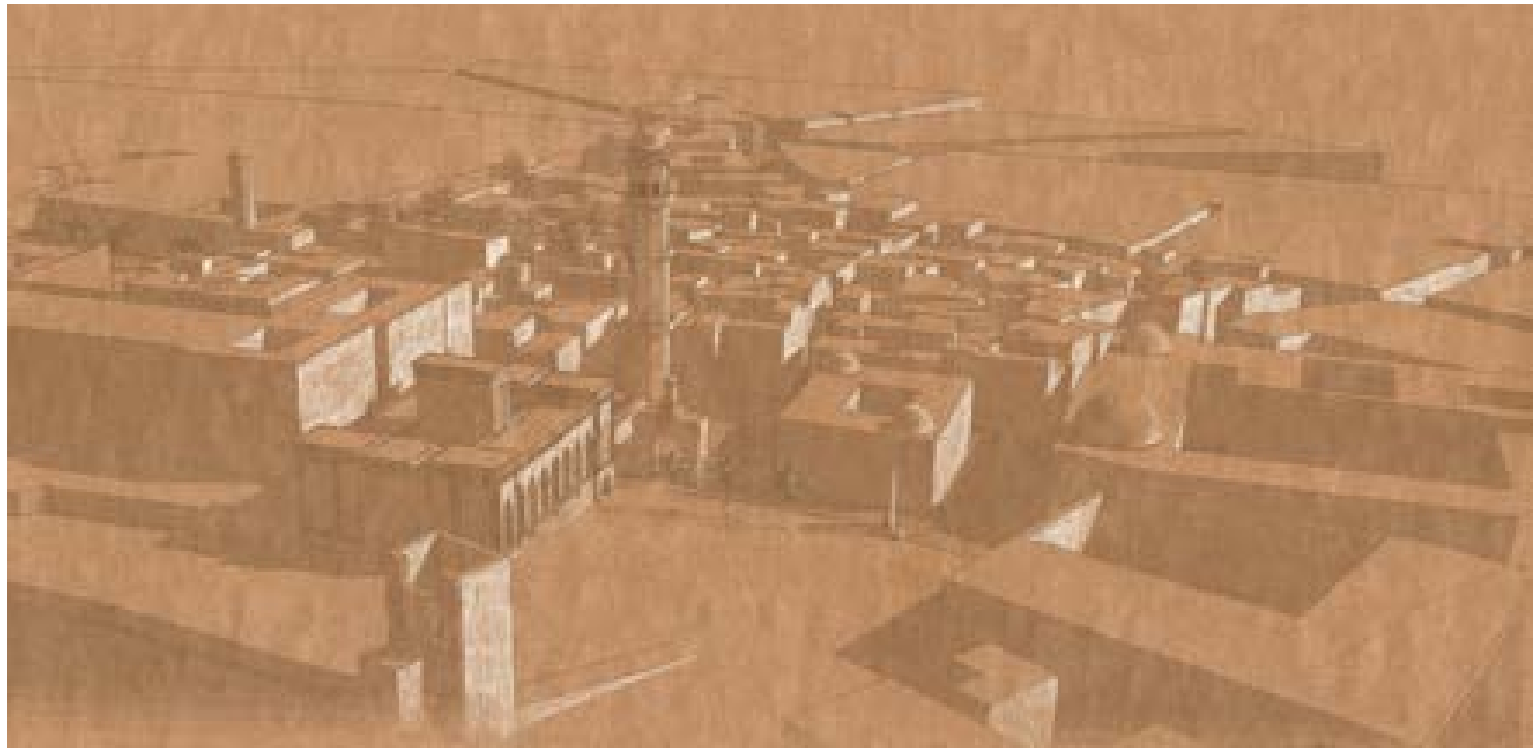

Aerial perspective of the proposal for the reconstruction of Aleppo: view from the Citadel of the reconstructed minaret in the cente and the proposed new Market Hall on the right (Luke Palmer)
Reconstruction of Aleppo was the topic of my fourth-year studio at the University of Notre Dame in spring 2018. Civil war was still raging in Syria and all the Middle and Near East seemed torn by indefinite strife. Terror, proxy-war politics, bombing and gassing of civilians and the deliberate destruction of cities and historic landmarks seemed an unpropitious context for even thinking of reconstruction; yet my students and I wished to offer a vision of hope and relief, as well as a sustainable project of peace, reconciliation, and healing.

The world has never been at peace for long and is alas often struck by natural or manmade tragedies; if golden ages ever existed, they were rare and short-lived. So here we commemorate the heroic and compassionate resilience of human responses to destruction and draw inspiration from epic efforts to rebuild a finer world over the ruins of old cities and memories.

My thanks to my students Cynthia Sigler, Eva Baghdan, Madeleine Donohue, Patrick Keough, Spicer Emge, Cole Rembecki, Sean Gaouette, Matthew Digoy, and Luke Palmer. They put their talent, intelligence, passion, and dedication into researching and designing a project for rebuilding Aleppo. The outcome is a moving tribute to the people of Syria and also quite an achievement in urban design and architecture.

\section{Destruction and reconstruction}

The genuine alternative for most of us is that between an aimless utopia of escape and a purposive utopia of reconstruction (Mumford 1922)

Life is a permanent process of reconstruction. The incapacity to rebuild results in an incapacity of life. Death is nothing but a definitive interruption of reconstruction, which though following a fixed plan and order, nevertheless allows infinite and always new and individual variations. (Krier) 
In 1684, prior to the Nine Years' War (1688-1697), the armies of Louis XIV bombarded the city of Luxembourg. A beautiful, fortified city of about 10,000 inhabitants was laid to waste by superior French artillery and powerful cannons. After assessing the damage, the French brought in 5,000 masons and craftsmen from Italy and Austria who, supervised by French engineers, rebuilt the city in five years. It was a masterful reconstruction, improving upon the original.

In April 2009, an earthquake in Abruzzo, Italy, killed 300 people, wreaking havoc and leaving 65,000 homeless. The historic center of the city of L'Aquila was near the epicenter and many of its buildings were destroyed. Five years later little or nothing had been done in the way of reconstruction, except for some limited, suburban, almost tragicomic architectural experiments showcased by the Berlusconi government.

I have been dismayed by the ongoing destruction of many cities in the Near and Middle East, from Gaza to Syria, Iraq, Libya, Yemen, etc., and when I returned to my notes of some years ago, it came back to me how important the issue of reconstruction had been in my early understanding of what architecture is about. I vividly remember reading Léon Krier and Maurice Culot's joint publications, particularly the Déclaration de Bruxelles, where they wrote eloquently of the urgency of a "moral and material" reconstruction. In an early interview, Léon Krier recounted in a poetic manner the reconstruction of Echternach in the 1950s as a paradigm of this "material and moral" endeavor. Both Léon and his brother Rob refer to this excellent reconstruction, executed by skilled local craftsmen and architects, as an almost legendary undertaking. Witnessing how a small country was able to rebuild its villages, towns, and cities consistently and elegantly after the war, and then seeing their destruction by modernist architecture, functional zoning and traffic planning in the following decades, shaped their thinking and their own designs.

The pairing of "moral and material" in reconstruction was particularly suggestive in my own studies and development. But I was never attracted by the "moralism" of fundamentalist modernism or doctrinaire classicism; my main reasons for studying architecture had to do with social justice, sense of place and the "common good", not with "morality", tainted by strict interpretations of religion and ideology.

Cities are extraordinarily resilient places, as we witnessed immediately after September 11 in New York City, and adversity, far from undermining civic confidence, can bring about a renewed and determined spirit of community and common endeavor (HRH The Prince of Wales. "Tall Buildings”. Invensys Conference, London, December 11, 2001)

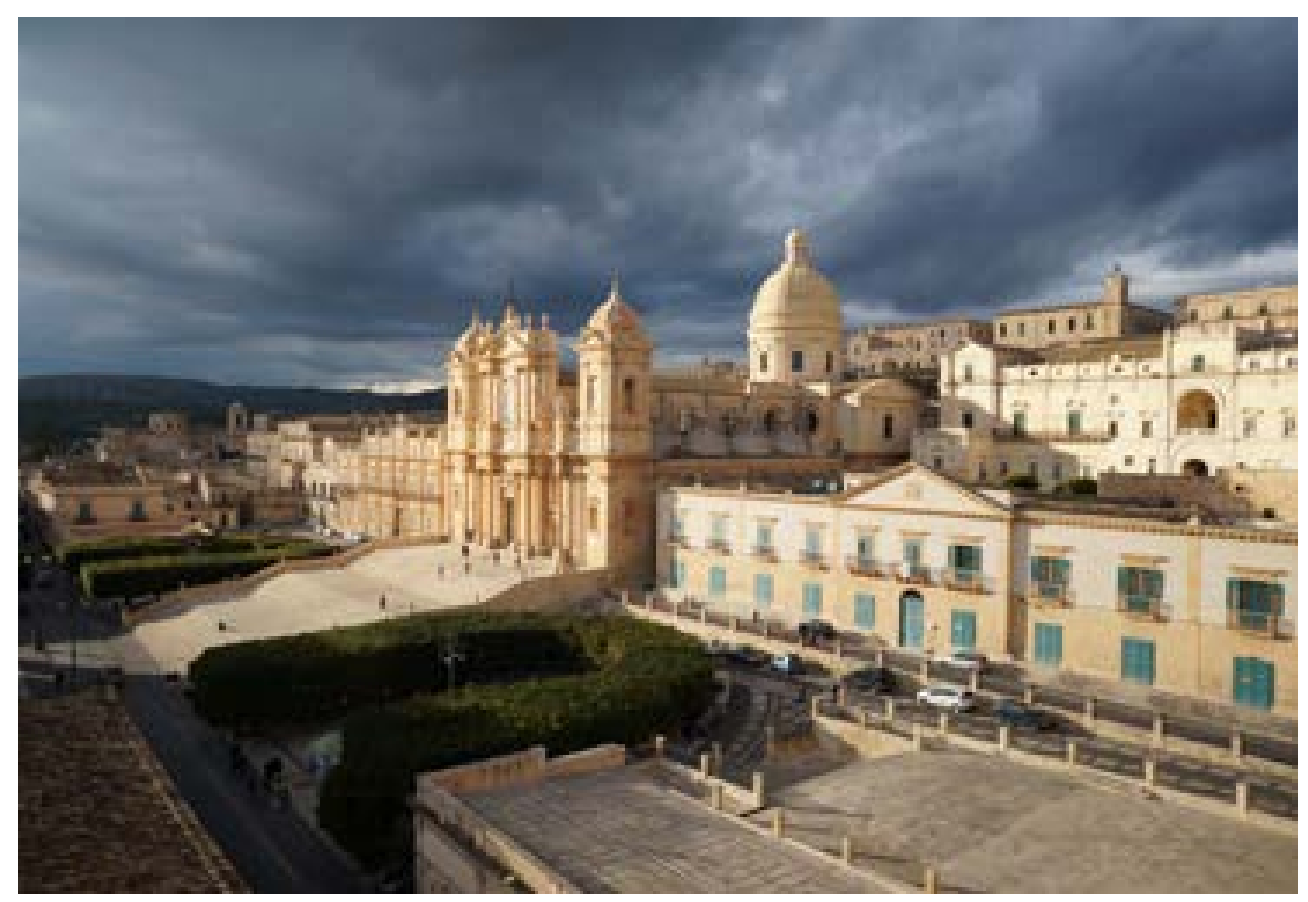

Noto, Sicily, with the cathedral rebuilt in Sicilian Baroque architecture (1776) after the 1763 earthquake which destroyed the city and its monuments (Leandro Neumann Ciuffo, viaWikimedia Commons) 
World Trade Center reconstruction proposal in New York, by Steve Peterson and Barbara Littenberg (Peterson and Littenberg Architects)
Let us recall some fine examples of reconstruction from the history of city-building and architecture: Warsaw after the Second World War, Lisbon admirably rebuilt by the Marquis of Pombal after the devastating earthquake of 1755, Catania in Sicily reinvented as a baroque masterwork after the earthquake of 1693, Luxembourg rebuilt after the heavy-handed assault by the troops of Louis XIV in five years by French architects and Italian and Austrian masons, Brussels rebuilt after its destruction by the same state-of-the-art French army in 1695, the cities razed during the Spanish Civil War and wonderfully rebuilt afterwards, and many other examples. My hometown, an industrial city of 25,000 inhabitants, has been wrecked and rebuilt more than twelve times since the Middle Ages, and indeed hardly any European city has escaped the cycle of destruction and reconstruction. There are innumerable examples of cities wrecked by natural causes and often by human havoc, and yet most have been followed by accomplished reconstructions.

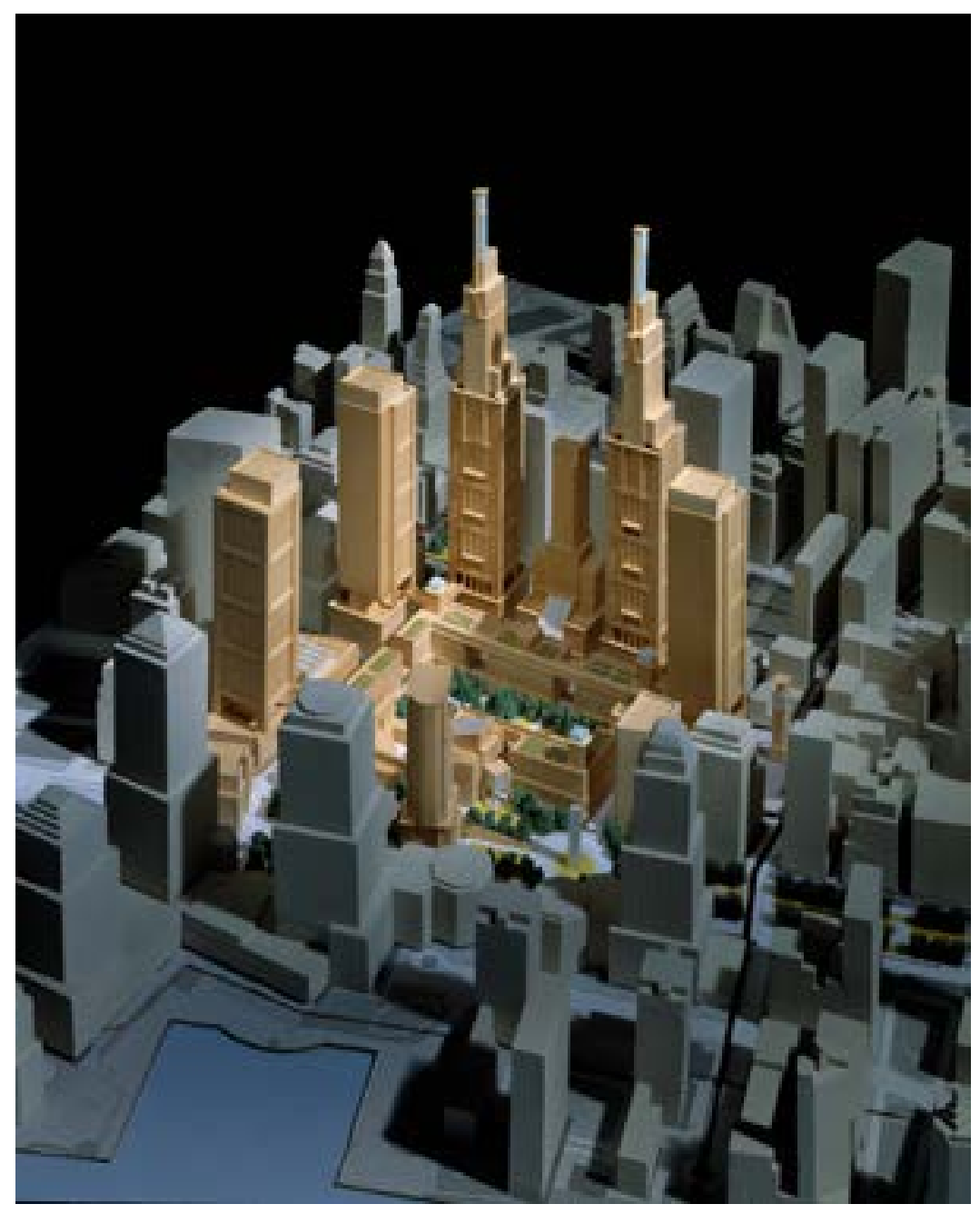

Though historical reconstructions were generally conceived as imitations of destroyed cities, the memories they sprang from were never straightjackets for imagination and recollection. The rebuilders were not bound by nostalgia but rather saw their task as a creative and poetic opportunity. Free of the dogma of archaeological authenticity, literal restitution, or folkloric mimicry, they were unashamed to borrow, copy, and imitate where appropriate, and to innovate where necessary or useful. They were not particularly concerned with expressing a "spirit of the time", or at least not as posited by modernism. It probably seemed evident that their buildings should fit into their settings and that the "spirit of the time" was an inherent condition of human existence in the world. The best reconstructions were not meant to manipulate, censor, or distort memory with emotion or sentimentality. There was no retribution, manifesto, or utopia, but rather an expression of human solidarity, patriotism, and culture. 


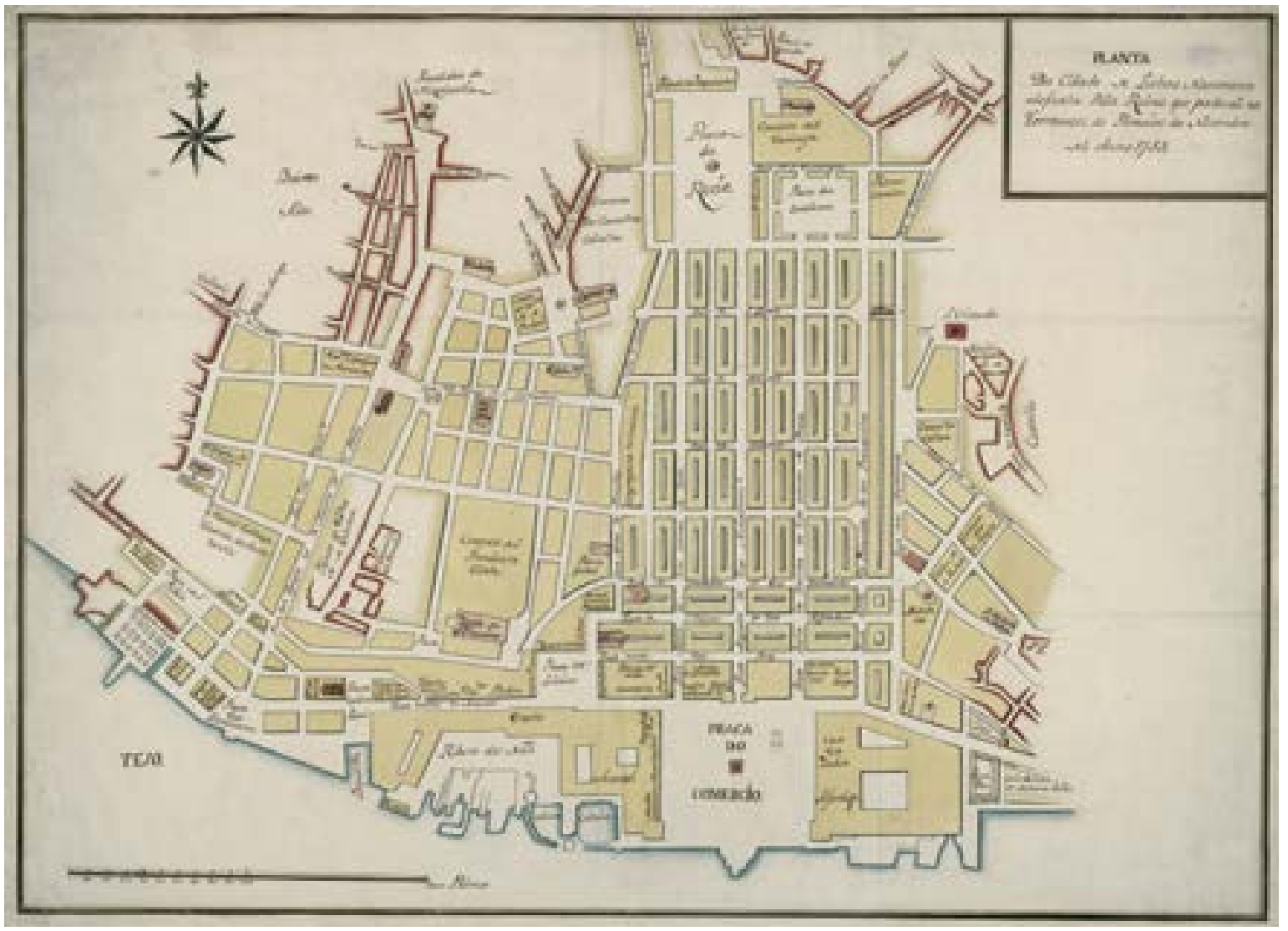

Our Reconstruction of Aleppo project addresses urban architecture in the specific context of Syria's post-Civil War reconstruction. We chose one of the most damaged yet remarkable neighborhoods located at the foot of the Citadel among various central areas to be rebuilt within a perspective of "philological reconstruction" in both their urban and their architectural forms. The site was chosen for its symbolic and historic significance and complexity in the context of its contemporary and historical civic, architectural, and urbanistic identity and collective memory. Students worked in small planning groups to research, analyze and sketch various iterations of a masterplan to be synthesized afterwards in a single draft. Drawing upon local precedents through typo-morphological analysis and research, the final plan was based on principles of "philological reconstruction" (with reference to Paolo Marconi and Léon Krier) and developed through a methodology of "imitation" (Léon Krier and Demetri Porphyrios, 1980) and "pattern language" (Christopher Alexander, 1977), allowing students to quickly draft a coherent, contextual, and empathic reconstruction model. They then focused individually on the design of a building or built ensemble using similar techniques of "imitation"; they sought to recover the "originality" of the place by returning to the origins and essences of placemaking and architecture in Aleppo.
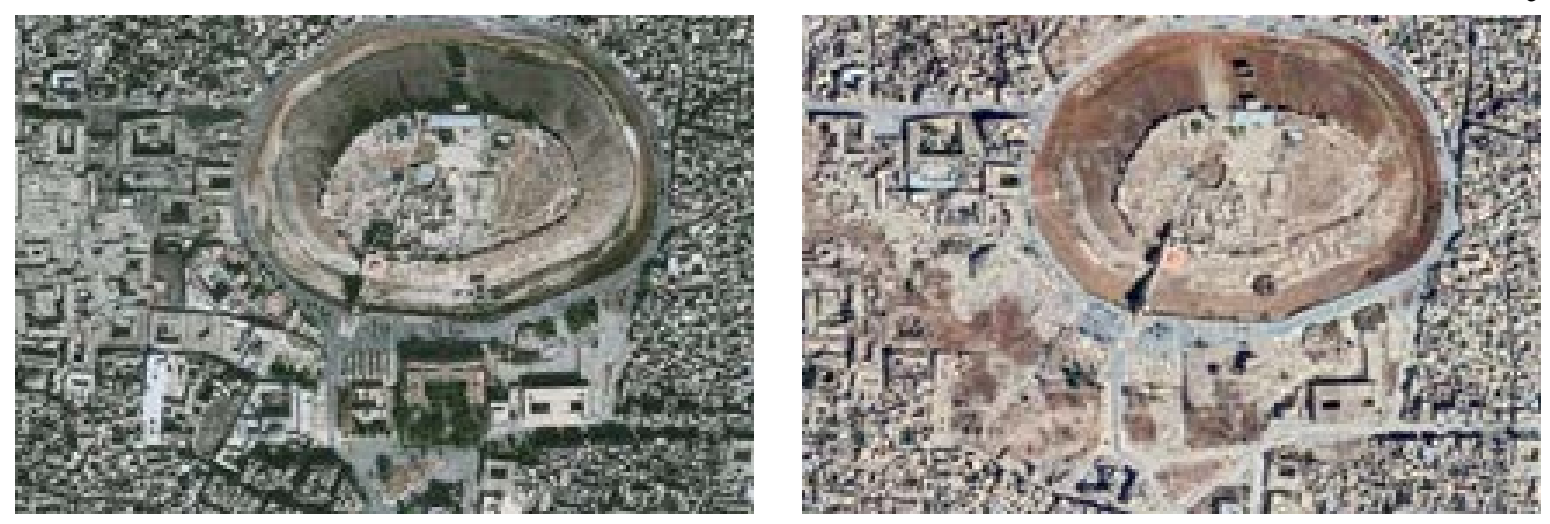


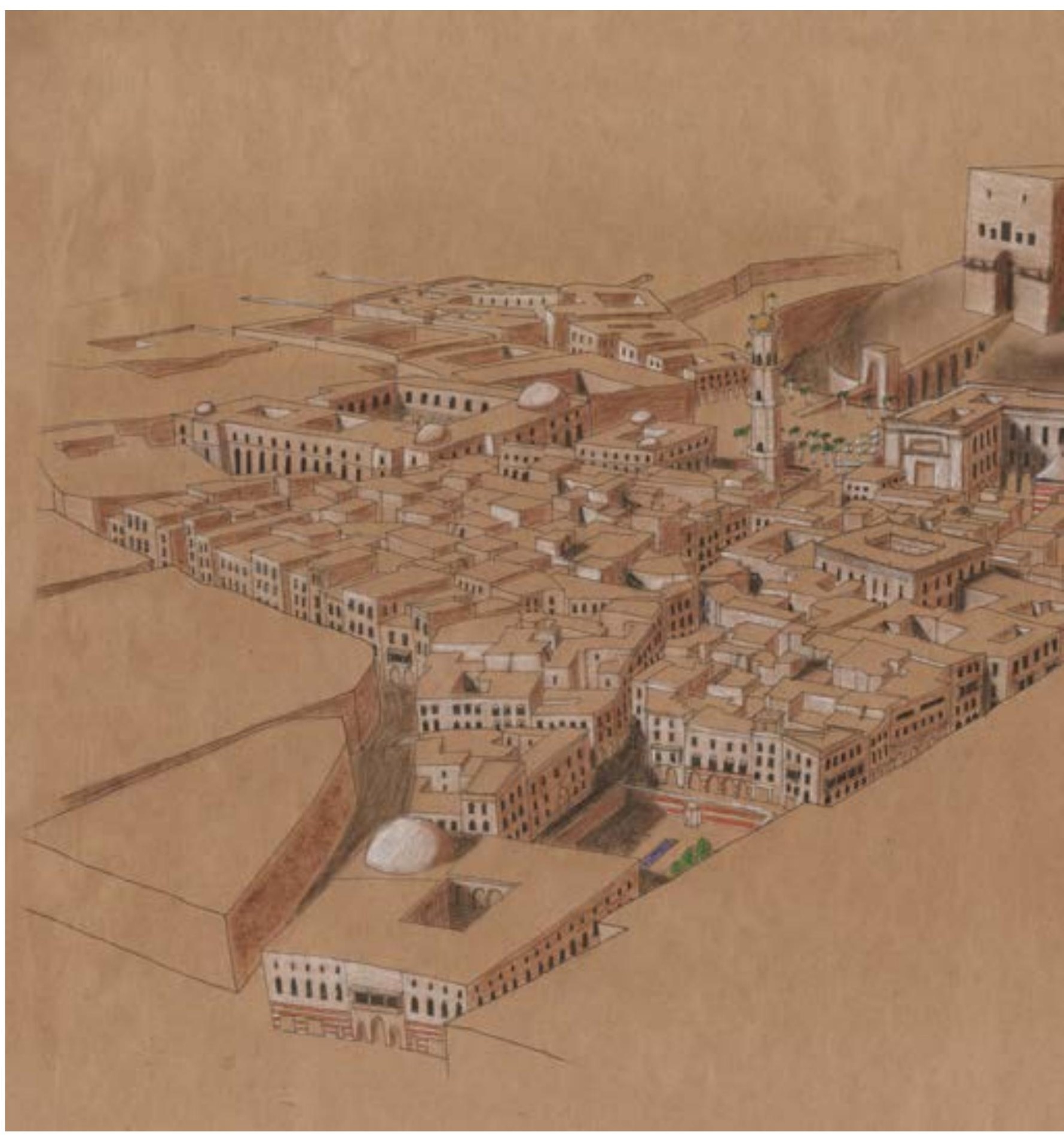

\section{Proposal for the reconstruction of Aleppo}

The purpose of the Aleppo reconstruction exercise was manifold: it was intended above all as a homage to the resilience of Syria and its people in a tragic moment of its history. Our premise was that an empathic and traditional reconstruction is necessary as both a civic and an ecological endeavor. With our project we intended to restore, heal, and enhance a city which has nurtured great achievements in urban culture and civilization and inspired artistic, political, scientific, and poetic imaginations. So the undertaking also highlighted the rich geometric, symbolic, and ornamental complexity of Islamic architecture and its wealth of architectural heritage worldwide. 


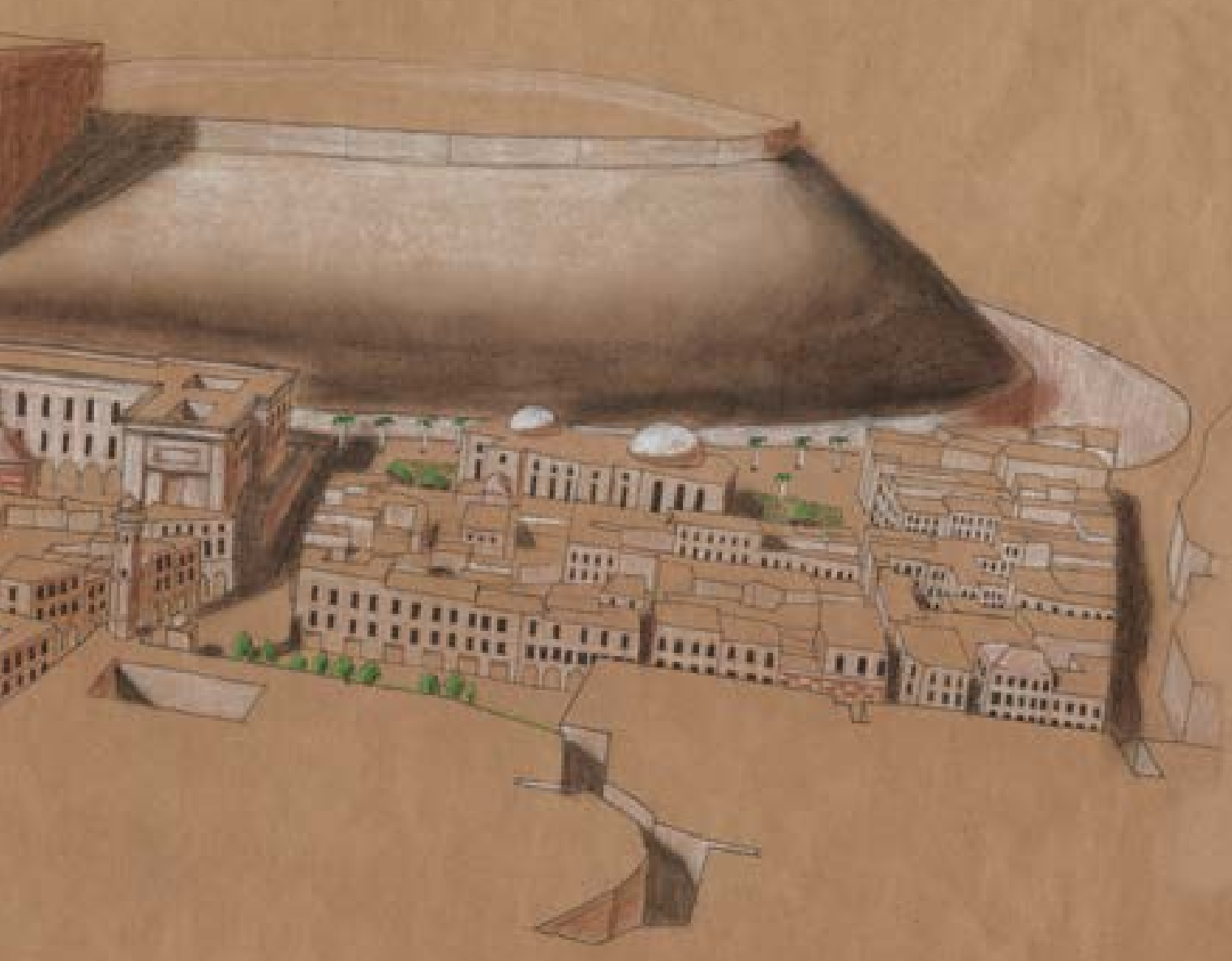

Aerial Perspective of reconstructed Aleppo near the historic Citadel

(Spicer Emge and Cole Rembecki)

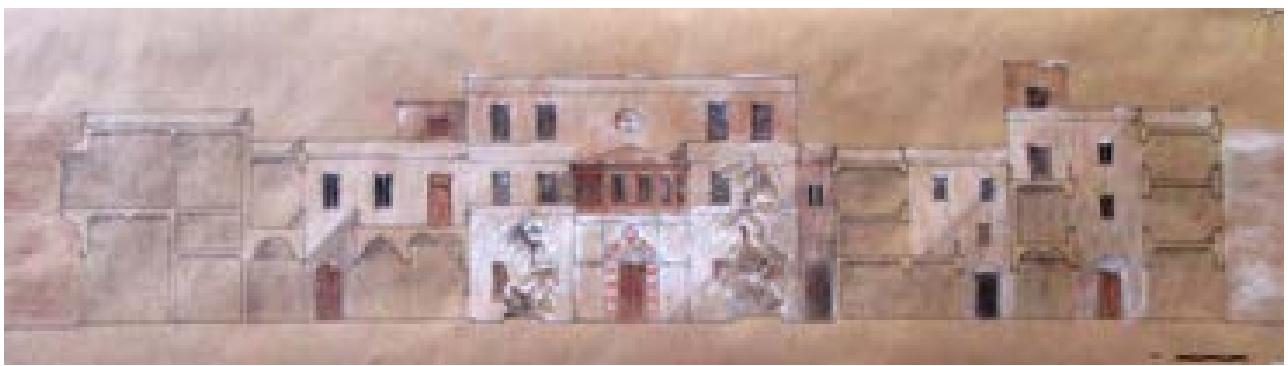

Elevation studies for typical urban fabric (Cynthia Sigler) 
Aleppo reconstruction design area

before the war destruction (left) and with the proposed philological reconstruction (right)
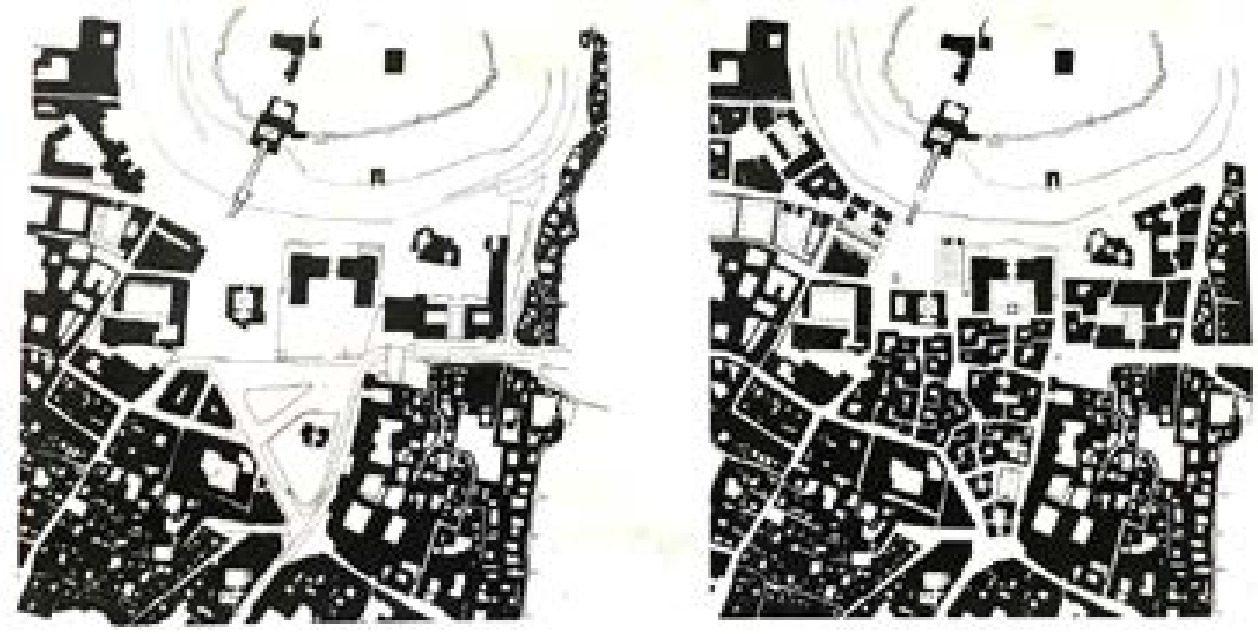

We were studying the principles of Islamic city-building as well as considering issues such as climatic, geographic, and cultural sustainability. Dialectics between vernacular and classical architecture, architecture and urbanism, etc. also featured large. The Aleppo project was moreover an opportunity to address the wider issues of destruction and reconstruction and also commemoration with reference to historical examples of urban reconstruction, as mentioned

Proposed Masterplan for the above.

reconstruction of Aleppo

Collaborative design studio work

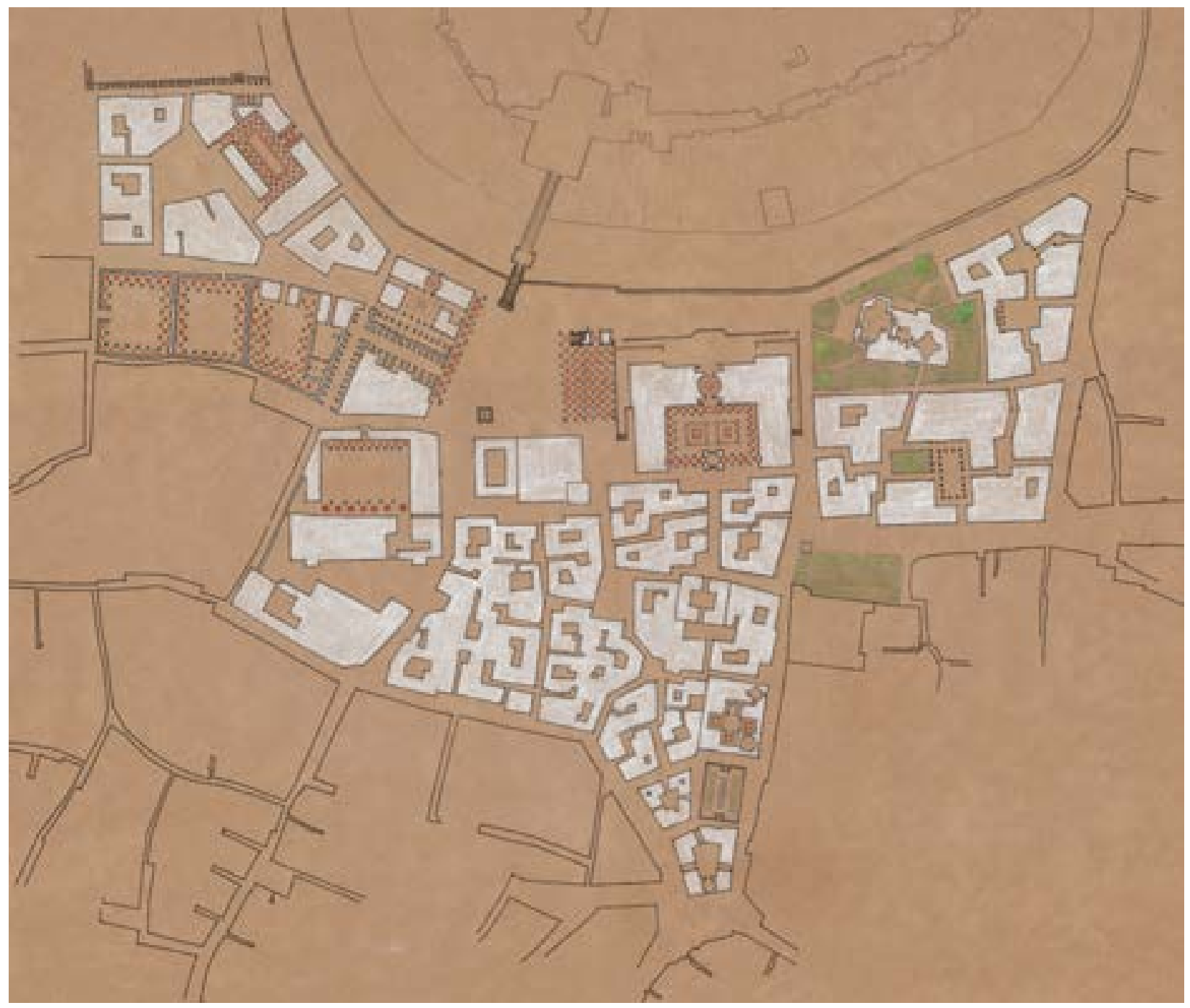


On studying precedents such as Lisbon, London, Warsaw, Luxembourg, Catania, etc., where the aim was largely to rebuild the new as a perfected image of what had been lost through natural or manmade destruction, we were able to apprehend the universality of humanity's aspiration to inhabit this world peacefully with permanence, comfort, and pleasure.

The block structure for the reconstructed Aleppo is derived from morphological and typological studies of traditional block patterns in historic Aleppo. Rather than replicating the previous fragmented condition or experimenting with interpretations, our strategy aspires to a "philological reconstruction": it refers to "imitation" as a technique encompassing both a respect for traditional principles of placemaking and a rigorous implementation of familiar types, tectonics, and building precedents, albeit refined, updated and refreshed.
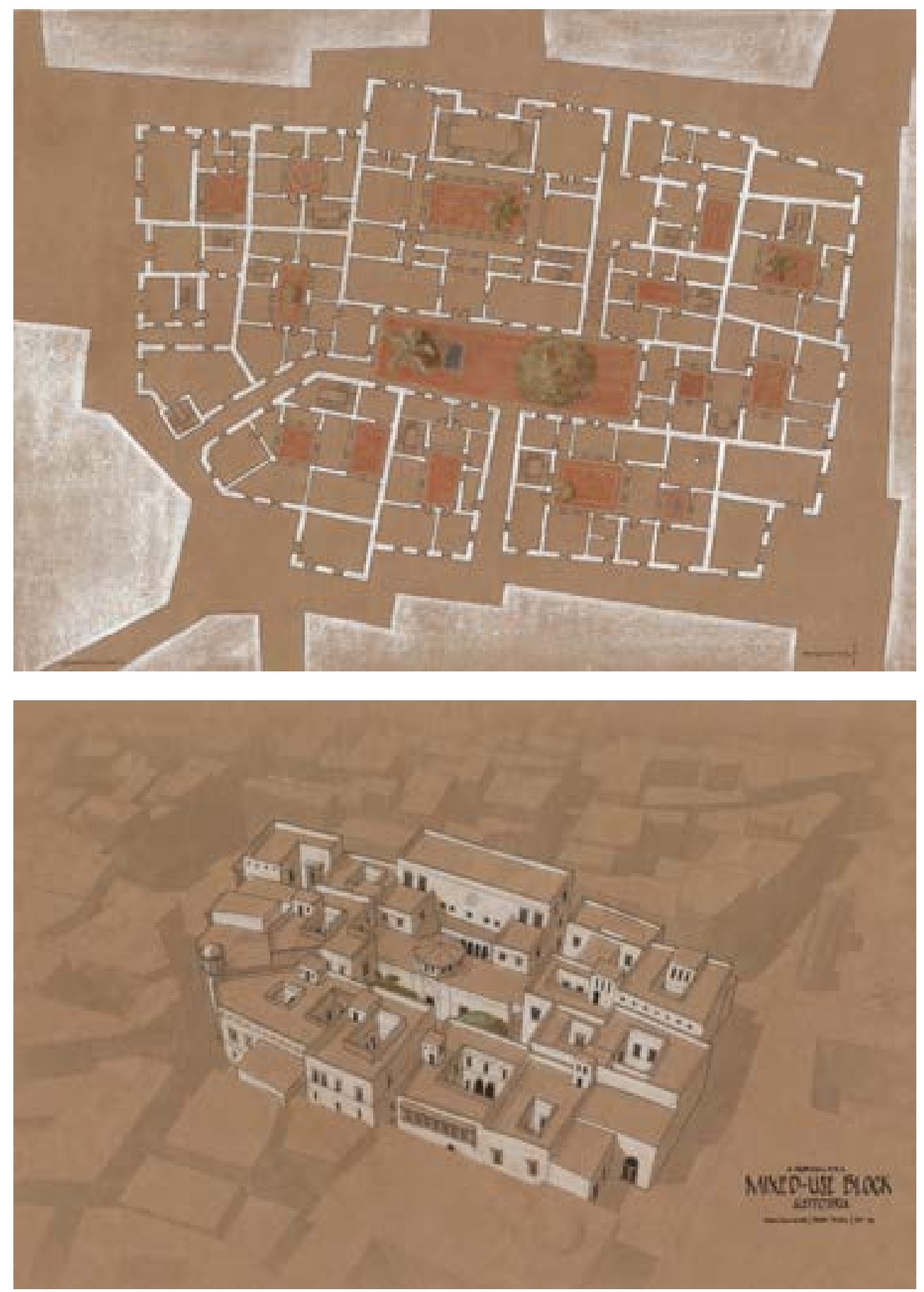

Plan and aerial view of the typical mixed-use block structure for reconstructed Aleppo (Cynthia Sigler and Sean Gaouette) 
Main elevation of Market Hall (Luke Palmer)

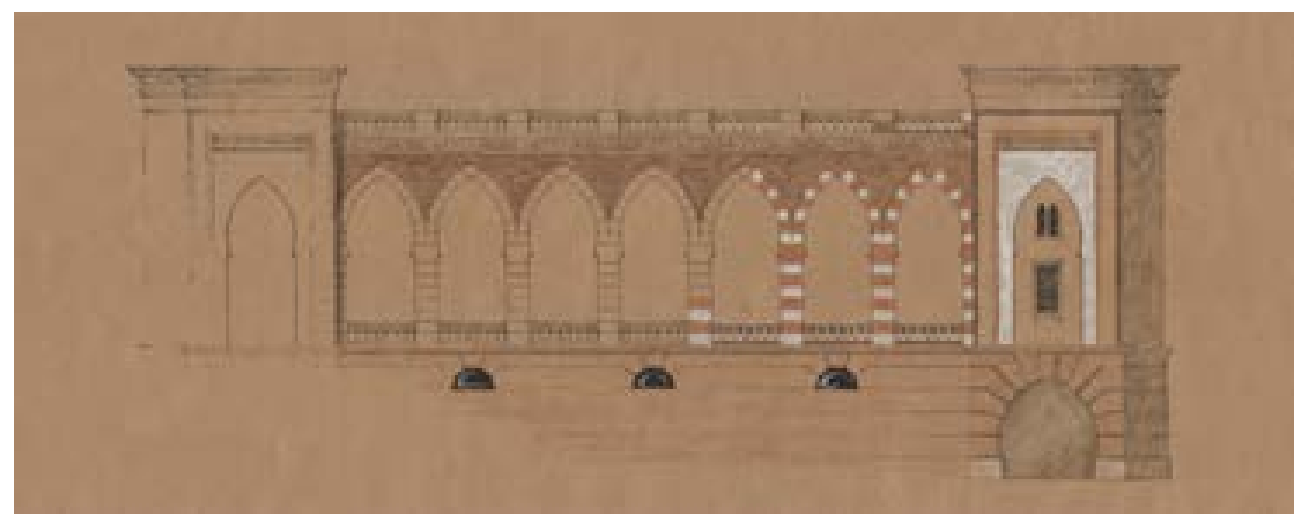

\section{References $\mid$ Referencias $\mid$ Referências}

Alexander, Christopher et al. 1977. A Pattern Language. New York: Oxford University Press.

Barey, André (ed.). 1980. Declaration de Bruxelles. Propos sur la Reconstruction de la Ville Européenne. Brussels: Archives d'Architecture Moderne.

Krier, Leon. 2013. La arquitectura de la comunidad: La modernidad tradicional y la ecología del urbanismo. Barcelona: Editorial Reverté.

Krier, Leon. 2018. The end of hypocrisy: On the reconstruction of the Frankfurt Old Town houses. In García Hermida, Alejandro (ed.): The Reconstruction of Cultural Heritage, 103-130. Madrid: Arcadia Mediática.

Marconi, Paolo. 2003. Il recupero della bellezza. Milan: Skira Editore.

Mumford, Lewis. 1962 [1922]. The Story of Utopias. New York: Viking Press.

Porphyrios, Demetri, ed. 1992. Classical Architecture: The Living Tradition. New York: McGraw Hill.

\section{Biographies | Biografías | Biografias}

\section{Lucien Steil}

He was born in Joao Monlevade (Brazil), and lived and studied in Luxembourg. He studied architecture and urbanism in Paris and Vincennes and graduated as an Architecte DPLG (Diplômé par le gouvernement). He has collaborated with Maurice Culot and Léon Krier at the Archives d'Architecture Moderne, in Brussels, and later with Colum Mulhern in Luxembourg. "Mulhern \& Steil” produced a wide range of projects in traditional urbanism and traditional architecture. Lucien Steil has lectured and taught at the Prince of Wales's Urban Design Task Force in Potsdam and Berlin, the Oregon School of Design (Portland, Oregon), the University of Miami, the Universidad Politécnica de Puerto Rico, the University of Notre Dame in Rome and in Indiana, the Università di Bologna, the Universidade Católica Portuguesa in Viseu, the Prince's Foundation and the University of Buckingham. He has been actively involved in traditional and ecological urbanism and architecture, which have become central to his teaching and design practice. Lucien Steil was the editor of Katarxis and principal of "Katarxis Urban Workshops ASBL".

\section{With Students:}

Cynthia Sigler (HKS Architects, Chicago, Illinois), Eva Baghdan (Solomon Cordwell Buenz, Chicago, Illinois), Madeleine Donohue (Appleton Partners, LLO, Santa Monica, California), Luke Palmer (Wade Weissmann Architecture, Milwaukee; Wisconsin), Patrick Keough (J. Ryan Duffey Architect, Atlanta, Georgia), Spicer Emge (Dibello Architects, Austin, Texas), Cole Rembecki (Torti Gallas + Partners, Washington DC), Matthew Digoy (Torti Gallas + Partners, Washington DC), and Sean Gaouette (Torti Gallas + Partners, Washington DC). All students graduated in May 2019 with a professional degree in architecture at the University of Notre Dame. 